\title{
水耕培養液へ添加する $\mathrm{NaCl}$ 濃度がインゲンの蒸散速度 に及ぼす影響の記述モデル
}

\author{
田附明夫 \\ 茨城大学農学部 300-0393 茨城県稲敷郡阿見町中央 3-21-1
}

\section{A Descriptive Model of the Effect of NaCl Concentration Added to the Nutrient Solution on the Transpiration Rate of Snap Bean}

\author{
Akio TAZUKE \\ College of Agriculture, Ibaraki University, Ami, Ibaraki, 300-0393, Japan
}

\begin{abstract}
Snap bean (Phaseolus vulgaris L.) plants were grown in culture containing Hoagland No. 2 solution. When two trifoliate leaves had expanded, the plants were transferred to a growth chamber. The growth conditions were: day and night temperature, $26^{\circ} \mathrm{C}$; relative humidity, $40 \%$; day length, $12 \mathrm{~h}$; PAR, $800 \mu \mathrm{mol} \mathrm{m}^{-2} \mathrm{~s}^{-1}$. After acclimation for more than one day, 0 to $200 \mathrm{mM} \mathrm{NaCl}$ was added to the nutrient solution at $1200 \mathrm{~h}$. The experiments were performed at least three times. The relative value of the transpiration rate 90 minutes after the treatment $(\mathrm{T})$ compared with the initial value fitted well to a logistic equation: $\mathrm{T}=$ $0.825 /(1+\exp (0.0528(\mathrm{x}-71.8)))+0.209$, where $\mathrm{x}$ is $\mathrm{NaCl}$ concentration $(\mathrm{mM})$. The standard deviation of the transpiration rate 90 minutes after the treatment was low at $\mathrm{NaCl}$ concentrations of $0-40 \mathrm{mM}$ and $100-200 \mathrm{mM}$, and high at $50-90 \mathrm{mM}$. This pattern of variability was reproduced well by introducing a noise term to the equation: $\mathrm{T}=0.825 /(1+\exp (0.0528$ $(\mathrm{x}-71.8+11.1 \mathrm{e})))+0.209$, where $\mathrm{e}$ is standard Gaussian noise. The $\mathrm{y}$-coordinate of the center of gravity of the leaf area relative to the value at the beginning of the treatment correlated with $\mathrm{T}(\mathrm{r}=0.9182)$.
\end{abstract}

Keywords: salinity, stress response, threshold

\section{緒言}

環境ストレスは作物の生産性の大きな制限要因であるの で ${ }^{1)}$, 環境ストレス反応のモデル化は生産予測に有用であ る. 多くの場合, ストレス反応はストレスを横軸にとると作物の 成長は右下がりの連続的曲線で表されると仮定されている. しかしながら, Tazuke ${ }^{2,3)}$ は溶存酸素濃度が低い水耕培養 液に $\mathrm{NaCl}$ を 50 または $60 \mathrm{mM}$ 添加して栽培したキュウリの

2010 年 2 月 23 日受付

2010 年 10 月 1 日受理

Corresponding author: Akio Tazuke (tazuke@mx.ibaraki.ac.jp)
果実には, 相対成長率に対照と差がないものと大きく抑制さ れるものがあることを報告している. これは閾值付近での 0 か 1 の, 確率的挙動であると考えられた. その後 Tazuke ${ }^{4)}$ は 0 か 1 の考えに基づいてモデル化を行うと, 塩ストレスに対する 果実の成長反応の確率的挙動がよく再現できることを報告し た.このような 0 か 1 かの確率的挙動はストレス反応において キュウリ果実以外にも認められる一般的な現象である可能性 がある. 実際, 医学分野では生存一死亡, 健康一病気等の 0 か 1 かの現象が多くみられ, しばしば logistic 回帰によって 分析されている ${ }^{5}$. 植物においても生態学において種の存在 一不在が logistic 回帰によって解析されている ${ }^{6)}$. ストレス反 応や生理障害は一種の病気ともみられ, 同様の解析を行いう る可能性があるが, そのためにはまず, 反応が 0 か 1 かで記 
述できるかを調べなければならない. キュウリでは幼植物体の 画像処理により抽出した葉領域の重心 $\mathrm{y}$ 座標を萎れ指数とし て萎れを表わすことができた ${ }^{7)}$ 。予備実験において，比較的 低温期に栽培可能であり蒸散の研究に広く用いられている ${ }^{8)}$ インゲンについてもこの方法が適用できることが明らかになっ た. そこで, インゲン幼植物体を水耕し, 様々な濃度の $\mathrm{NaCl}$ で処理して, 蒸散速度と萎れ指数を指標にして閾值付近のス トレス反応が確率的挙動を示すかどうかを調べた.

\section{材料および方法}

2008 年と 2009 年の秋にインゲン (Phaseolus vulgaris L.) ‘アーロン’ を研究室の南向きの空際に置いたバーミキュラ イトを詰めた素焼き鉢 (直径 $22 \mathrm{~cm}$, 容量 $3 \mathrm{~L}$ ) に週 2 回月曜 日と金曜日に 8 粒播種し, 初生葉展開時に 3 株を水耕に移し た. 培養液の組成は Hoagland No. 2 液とした. 水耕容器に は $1 \mathrm{~L}$ 容のポリエチレン製ビーカーの外側に遮光のため銀色 のラッカーを塗布したものを用い, 1 容器あたり 1 株を移植し た. 容器のふたには厚さ $0.3 \mathrm{~cm}, 12.5 \mathrm{~cm}$ 四方のプラスチック 板を用い, 中央部の直径約 $2 \mathrm{~cm}$ の穴から苗の根を通した. ふたに取り付けた直径約 $0.6 \mathrm{~cm}$, 長さ $20 \mathrm{~cm}$ のアルミニウム 製パイプに塩化ビニルテープで苗の茥を固定した. ふたに開 けた直径約 $0.6 \mathrm{~cm}$ の穴を通して通気用のチューブを培養液 に入れ, 1 株あたり約 $0.3 \mathrm{~L} \mathrm{~min}^{-1}$ の通気を行った. 培養液の $\mathrm{pH}$ は毎日 6.0 に調整した.

約 2 週間後の第 3 本葉展開時に苗を環境制御室に移し, 1 日以上順化させた. 環境制御室は設定温度を $26^{\circ} \mathrm{C}$ 一定と し, 相対湿度は $40 \%$ 一定とした. 光源には高圧ナトリウムラン プ (IAN-361FL, 日本電池 ) 2 基を用いた. 熱線は水フィル夕 一によって除去した. 第 3 本葉の高さにおける光量は光合成 有効光量子束密度で $800 \mu \mathrm{mol} \mathrm{m}^{-2} \mathrm{~s}^{-1}$, 熱量で $200 \mathrm{~W} \mathrm{~m}^{-2}$ だった. 明期は 6 時から 18 時までの 12 時間とした.

測定前日の夕方に, 容器ごと苗を電子天科 (Sefi IB2000H, 井内 ) に乗せ, 翌日の 10 時に電子天秤の出力を開 始させ, それをパーソナル・コンピュー夕によって記録した. 電 子天秤の重量は 10 秒ごとに記録し, ある時点の 1 分前の值 から 1 分後の值を引いて数值微分し, 平滑化のため求めた 微分值を前後 1 分間について平均する移動平均をとって蒸 散速度を求めた. その結果, 蒸散速度の時間分解能は \pm 2 分となった. なお, 通気用のチューブは電子天秤近くの床面 を這わせたが, 予備実験の結果, このようにしても蒸散速度 の測定值に影響がないことが確認された. 重量法による蒸散 測定は一般的であり, 例えば舘野 ${ }^{9)}$ がヒートパルス法との比 較に用いている. 正午に苗を支持体ごと処理溶液を入れた容 器に移し, その後約 2 時間蒸散速度の測定を継続した.
処理溶液は Hoagland No. 2 等倍液に $\mathrm{NaCl}$ を加え, $\mathrm{NaCl}$ 濃度を 0 (0), 10 (0.04), 20 (0.08), 30 (0.13), 40 (0.17), 50 (0.21), 60 (0.25), 70 (0.29), $80(0.33), 90$ (0.37), 100 (0.41), 110 (0.45), 120(0.49), 130 (0.53), 150 (0.61), 200 (0.80) $\mathrm{mM}$ とする処理を設けた. 括弧内の数字はその濃度 の $\mathrm{NaCl}$ 水溶液の浸透圧 $(\mathrm{MPa})$ である. Hoagland No. 2 等倍液の浸透圧は $0.06 \mathrm{MPa}$ である. $60,100 \mathrm{mM}$ 処理は 4 回ずつ, $70,80,90 \mathrm{mM}$ 処理は 5 回ずつ行い, それ以外の 処理は 3 回ずつ行った. このように処理濃度によって処理回 数が異なる理由は次のとおりである. 当初全ての処理を 3 反 復したが, 70 〜 $90 \mathrm{mM}$ では顕著に, $60,100 \mathrm{mM}$ ではそれ に準じて蒸散速度や目視した萎れの程度が大きくばらついて いた. そこで, これらの濃度で平均值や標準偏差をより正確 に把握するために処理回数を増やした.

処理開始と同時に田附・塩 ${ }^{7)}$ の方法で植物画像の保存を 開始した. 植物画像の保存は 5 分おきに行った. 得られた植 物画像の重心 $\mathrm{y}$ 座標を田附ら ${ }^{10)}$ の方法で求め, その初期 值に対する相対值を萎れ指数とした.

\section{結果および考察}

処理 90 分後には蒸散速度が安定していたので, 処理 90 分後の蒸散速度の処理時に対する相対值を $\mathrm{NaCl}$ 濃度に対 してプロットしたのが Fig. 1 である. 処理 90 分後の萎れ指 数を $\mathrm{NaCl}$ 濃度に対してプロットしたのが Fig. 2 である. $\mathrm{NaCl}$ 濃度 0 〜 $60 \mathrm{mM}$ では顕著な萎れは生じず, 蒸散速度も大き 〈は低下しなかった. $\mathrm{NaCl}$ 濃度 $100 \mathrm{mM}$ 以上では顕著な萎 れが生じ, 蒸散速度が大きく低下した. $\mathrm{NaCl}$ 濃度 70 ～ 90 $\mathrm{mM}$ の反応は大きくばらつき, 顕著な萎れが生じ蒸散速度が 大きく低下するものと顕著な萎れは生じず蒸散速度も大きくは

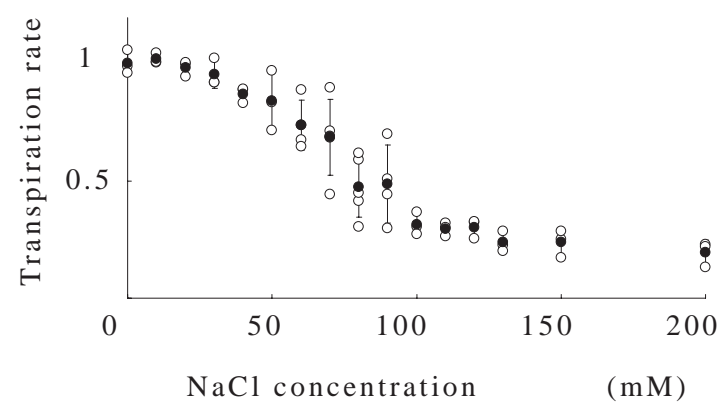

Fig. 1 The effects of adding $\mathrm{NaCl}$ at different concentrations to the nutrient solution on the transpiration rate of snap bean plant. The transpiration rate is expressed as the value relative to that at the time of treatment. Open circles: individual plants. Closed circles: average values. Vertical bars: standard deviations. 


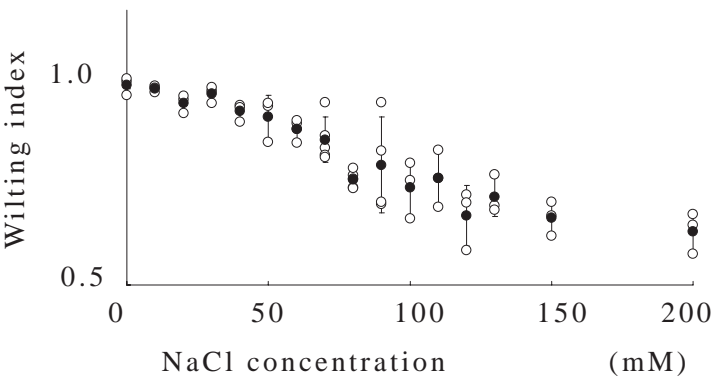

Fig. 2 The effects of adding $\mathrm{NaCl}$ at different concentrations to the nutrient solution on the wilting index of snap bean plant. The wilting index is the value of the $y$-coordinate of the center of gravity of the plant image relative to that at the time of treatment. Open circles: individual plants. Closed circles: average values. Vertical bars: standard deviations.

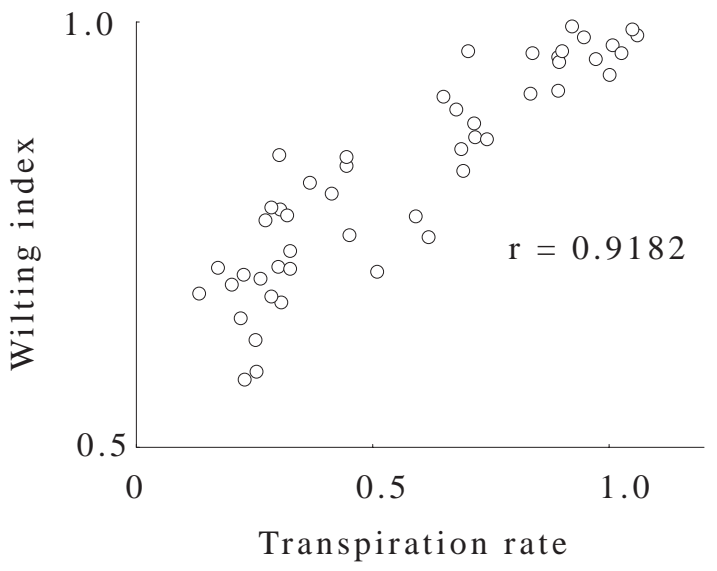

Fig. 3 Relationship between transpiration rate and wilting index 90 minutes after the addition of various concentrations of $\mathrm{NaCl}$ to the nutrient solution in snap bean plant. Both values are relative to that at the time of treatment. For a definition of the wilting index, see Fig. 2.

低下しないものがあった. Fig. 1, 2 を見ると, $\mathrm{NaCl}$ 濃度に対 する蒸散速度や萎れ指数の反応は必ずしも 0 か 1 かの確率 的反応ではなく, 平均值でみるとなめらかに低下している. し かし, 蒸散速度については 50 〜 $90 \mathrm{mM}$ で顕著にばらつき が大きく, 萎れ指数については 90 〜 $120 \mathrm{mM}$ でばらつきが大 きかった. このように, インゲンの $\mathrm{NaCl}$ に対する蒸散速度と萎 れ指数の反応はストレス反応の閾值付近でばらつきが大きい ものの連続的で, 明らかに 0 か 1 かの反応ではなかった。 こ れに対し，キュウリ果実の相対成長率の $\mathrm{NaCl}$ に対する反応 は相対成長率が 0 か 1 かに近い確率的反応を示し ${ }^{2-4)}$, 互

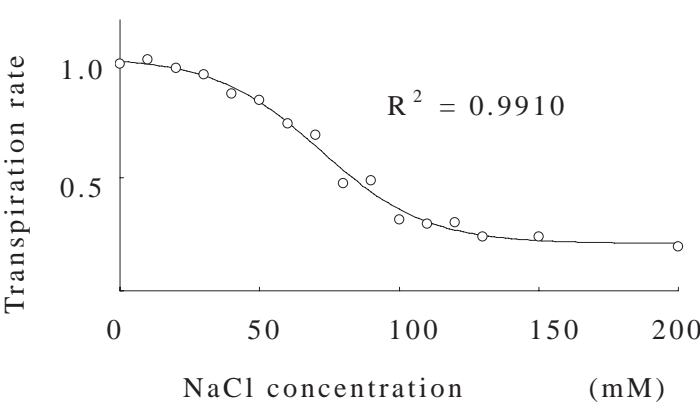

Fig. 4 Logistic equation: $\mathrm{T}=\mathrm{A} /(1+\exp (\mathrm{B}(\mathrm{x}-\mathrm{C})))+$ $\mathrm{E}$ fitted to the average values of transpiration rate (T) 90 minutes after the addition of various concentrations of $\mathrm{NaCl}$ to the nutrient solution of snap bean plant. The transpiration rate is expressed as the value relative to that at the time of treatment.

いに反応が異なっていた。

処理 90 分後の蒸散速度に対して処理 90 分後の萎れ指 数をプロットすると高い正の相関 $(\mathrm{r}=0.9182)$ が認められた (Fig. 3).このことは処理後しばらくは気孔が開いているが, 萎れ指数が検出する葉の傾きにより, 受光量が低下して蒸散 速度が低下すると考えれば説明できよう.

各濃度の蒸散速度の処理時を 1 とした相対值 $(\mathrm{T})$ の平均 值は $\mathrm{NaCl}$ 濃度 $(\mathrm{mM})$ を $\mathrm{x}$ としたとき次の logistic 曲線でよく 表された (Fig. 4).

$$
\mathrm{T}=\mathrm{A} /(1+\exp (\mathrm{B}(\mathrm{x}-\mathrm{C})))+\mathrm{E}
$$

ここで, パラメータ A, B, C, E は各濃度における平均值に 対する非線形最小二乗法で求めた. $\mathrm{NaCl}$ 濃度 $0 \sim 40 \mathrm{mM}$ および 100 ～ $200 \mathrm{mM}$ の範囲では蒸散速度のばらつきが小 さく, 50 〜 $90 \mathrm{mM}$ の範囲ではばらつきが大きかったが (Fig. 1), $50 \sim 90 \mathrm{mM}$ の範囲は logistic 曲線の変曲点 $(\mathrm{C}=71.8$ $\mathrm{mM})$, すなわち閾值に近い. 閾值付近でばらつきが大きいこ とは Tazuke ${ }^{4)}$ が報告しているキュウリ果実の相対成長率の 記述モデルの作成の過程で用いた最大成長速度の反応と類 似している. そこで, Tazuke ${ }^{4)}$ と同様に式

$$
\mathrm{T}=\mathrm{A} /(1+\exp (\mathrm{B}(\mathrm{x}-\mathrm{C}+\mathrm{De})))+\mathrm{E}
$$

に対する当てはめを行った. ただし, A, B, C, E は (1) で求め た值を用いた. e は標準正規乱数である. また, D は次式

$$
\mathrm{SS}=\sum\left(\mathrm{SD}_{\mathrm{s}, \mathrm{i}}-\mathrm{SD}_{\mathrm{o}, \mathrm{i}}\right)^{2}
$$

を最小化するように求めた. ここで $\mathrm{SD}_{\mathrm{s}, \mathrm{i}}$ は (2) 式の e に 100 個の標準正規乱数を与えて求めた標準偏差であり, $\mathrm{SD}_{0, \mathrm{i}}$ は 実測值の標準偏差である. i は各濃度を表わす。 


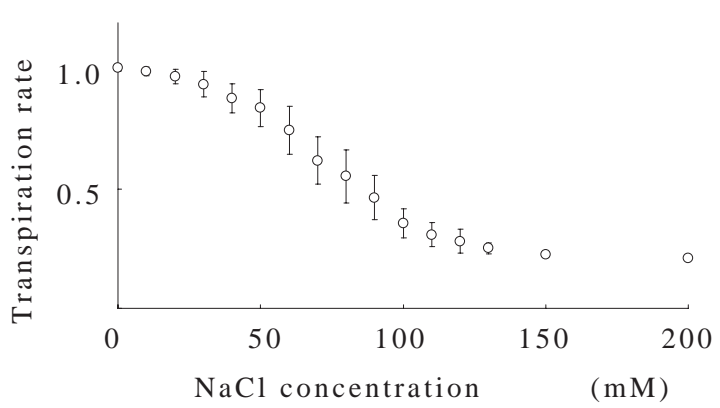

Fig. 5 Simulation of the variability of the transpiration rate (T) 90 minutes after the addition of various concentrations of $\mathrm{NaCl}$ to the nutrient solution of snap bean plant. The transpiration rate is expressed as the value relative to that at the time of treatment. The variability of $\mathrm{T}$ was simulated by the equation: $\mathrm{T}=\mathrm{A} /(1+\exp (\mathrm{B}(\mathrm{x}-\mathrm{C}+\mathrm{De})))$ $+\mathrm{E}$ where $\mathrm{x}$ is $\mathrm{NaCl}$ concentration $(\mathrm{mM})$ and $\mathrm{e}$ is standard Gaussian noise. Parameters A, B, C, and E were determined from the values in Fig. 4. D was defined to minimize the squared sum of the differences of the standard deviations.

この際, BASIC 言語により，D の值として0 から 100 まで の值を 0.1 間隔で与え, SS を最小化する D の值を採用した. こうして得られたコンピュータの疑似乱数を利用して求めた標 準偏差は実測值の標準偏差とよく一致した (Fig. 5). このこと は, パラメータ D の大きさによって幅広い現象について閾值 付近の挙動が記述できることを示すのかもしれない.

ストレス反応の記述に logistic 式を用いることは温度ストレ スに関して数多く報告されている ${ }^{11-15)}$. 高温や低温ストレス の限界温度として, 50\%の個体が枯死する温度 $\left(\mathrm{LD}_{50}\right)$ が広 く用いられている ${ }^{16)}$ が, このことは, ストレス反応においてば らつきが大きいことが広く認識されていることを示す.しかし ながら, 植物においては, 生態学を除いて反応のばらつきを 考慮してモデル化を行った例は少ないようである. Repo and Lappi $^{14)}$ はヤナギの茎のインピーダンスを指標に低温障害の 程度を測定し, 測定值を logistic 曲線に当てはめて, そのパ ラメー夕の推定值から障害が発生する温度の推定值の標準 誤差を推定した. ただし, 彼らの方法は本報のよう正規乱数 を導入するものではない.

(2) 式が塩害条件におけるキュウリ果実の相対成長率のモ デル化に损ける最大成長速度と塩害によるインゲン幼植物の 蒸散速度をよく表していたことは, (2) 式がストレス反応の記述 に広く用い得る可能性を示す. Tazuke ${ }^{4)}$ は, (2) 式をキュウリ 果実の最大成長速度として果実成長をモデル化したところ，0 か 1 かの確率的反応を得ているが, 本実験の蒸散速度につ いては 0 か 1 かの反応ではなかった. キュウリ果実の場合,
成長が急速で比較的長〈指数関数的に行われる ${ }^{17)}$ ため, 光 合成産物が欠方すると急激に相対成長率が低下し, 確率的 反応を示したと思われる.これは成長が抑制された果実のへ キソース濃度が低下したこと ${ }^{18)}$ や成長が抑制された果実の 成長速度が一定になったこと ${ }^{4)}$ から支持される. 一方，(2) 式 そのものは成長が抑制された果実の成長速度や本実験の蒸 散速度のような中間的值も含む反応を記述すると考えられる.

なお, 本実験で用いた萎れ指数は水ストレスによる葉の垂 れ下がりを見ていることになるが, 一方, 5 分間隔で保存され た植物画像から葉の縮れの有無が観察され, それは観察可 能か否かであるから原理的に 0 か 1 的である. そこで, 縮れ の有無を自動判別する方法や, 縮れの発生する条件につい て更に検討する必要があろう.

\section{摘 要}

インゲン (Phaseolus vulgaris L.) 品種アーロンの幼植物 体を Hoagland No. 2 液を用いて水耕育苗し, 第 2 本葉 完全展開時に環境制御室 (気温 $26^{\circ} \mathrm{C}$ 一定, 相対湿度 40 $\%$, 日長 12 時間, 光合成有効量子密度束 $800 \mu \mathrm{mol} \mathrm{m}^{-2}$ $\left.\mathrm{s}^{-1}\right)$ に移した. 1 日以上順化させた後, 正午に培養液に $\mathrm{NaCl}$ 添加して培養液の $\mathrm{NaCl}$ 濃度を 0 $200 \mathrm{mM}$ とす る処理を行った. 実験は少なくとも 3 反復した. 処理時の 蒸散速度に対する処理 90 分後の蒸散速度の相対值 $(\mathrm{T})$ は 50 〜 $90 \mathrm{mM}$ で大きくばらついたものの, 0 と 1 の間の中 間的值を取り, 反応は 0 か 1 的ではなかった. $\mathrm{T}$ の平均值 は $\mathrm{x}$ を $\mathrm{NaCl}$ 濃度 $(\mathrm{mM})$ として logistic 式 $\mathrm{T}=0.825 /(1+$ $\exp (0.0528(\mathrm{x}-71.8)))+0.209$ によく当てはまった. 閾值付 近におけるばらつきの増大は正規乱数項を導入することによ ってよく記述された： $\mathrm{T}=0.825 /(1+\exp (0.0528(\mathrm{x}-71.8+$ 11.1e) $))+0.209$, ここで $\mathrm{e}$ は標準正規乱数である. 植物画 像の葉領域の重心 $\mathrm{y}$ 座標の処理時に対する相対值は $\mathrm{T}$ と 高い相関があった $(r=0.9182)$. 本報はストレス反応のばらつ きに着目したものであるが, logistic 回帰が用いられないような 中間的な值を取る場合は, 本報で提案した方法が有用であ る可能性がある。

\section{引用文献}

1) Boyer JS. Plant productivity and environment. Science. 218: 443-448. 1982.

2) Tazuke A. Growth of cucumber fruit as affected by the addition of $\mathrm{NaCl}$ to nutrient solution. J. Japan. Soc. Hort. Sci. 66(3): 519-526. 1997.

3) Tazuke A. Effect of adding $\mathrm{NaCl}$ and reducing aeration to nutrient solution on the growth of cucumber fruit. J. 
Japan. Soc. Hort. Sci. 66(3): 563-568. 1997.

4) Tazuke A. A descriptive model of the growth of cucumber fruit under salinity at low oxygen supply levels in the nutrient solution. Environ. Control Biol. 42(4): 267-276. 2004.

5) Wright RE. Logistic regression. In: Reading and Understanding Multivariate Statistics, eds. Grimm LG, Yarnold PR. American Psychological Association, Washington, DC. 217-244. 1995.

6) Dupre C, Diekmann M. Prediction of occurrence of vascular plants in deciduous forests of South Sweden by means of Ellenberg indicator values. Appl. Veget. Sci. 1(1): 139-150. 2009.

7）田附明夫, 塩 光輝. 数種浸透質の添加と無酸素また は通気停止処理によるキュウリ幼植物体の水ストレスの 画像解析. 園芸学研究. 6(3): 367-373. 2007.

8) Jones HG. Use of thermography for quantitative studies of spatial and temporal variation of stomatal conductance over leaf surfaces. Plant Cell Env. 22: 1043-1055. 1999.

9）舘野宏司. イネ科飼料作物のヒートパルス法による蒸散 流速と重量法による蒸散速度の比較. 日本草地学会誌. 30(2): 117-121. 1984.

10）田附明夫, 亀井清紀, 大倉更織, 水谷友香梨, 塩 光 輝. しおれ自動識別のための植物画像からの葉領域抽 出法. 農業情報研究. 11(1): 27-40. 2002.
11) Ingram DL, Buchanan DW. Measurement of direct heat injury of roots of three woody plants. HortScience. 16: 769-771. 1981.

12) Ingram DL, Buchanan DW. Lethal high temperature for roots of three citrus rootstocks. J. Amer. Soc. Hort. Sci. 109: 189-193. 1984.

13) Janacek J, Prasil I. Quantification of plant injury by nonlinear fitting of S-shaped function. Cryo. Lett. 12: 47-52. 1991.

14) Repo T, Lappi P. Estimation of standard error of impedance-estimated frost resistanse. Scand. J. For. Res. 4: 67-74. 1989.

15) Schaff DA, Clayberg CD, Milliken GA. Comparison of TTC and electrical conductivity heat tolerance screening techniques in Phaseolus. HortScience. 22: 642-645. 1987.

16) Proebsting EL, Mills HH, Russell TS. A standard temperature-survival curve for dormant Elberta peach fruit buds. Proc. Amer. Soc. Hort. Sci. 89: 85-90. 1966.

17）田附明夫, 崎山亮三. 着果状態におけるキュウリ果実 の体積推定と生長解析. 園芸学会雑誌. 53(1): 30-37. 1984.

18）田附明夫. 水耕培養液への $\mathrm{NaCl}$ 添加がキュウリ果 実の糖濃度に及ぼす影響. 生物環境調節. 39(4): 281-288. 2001. 